\title{
Resolving taxonomic ambiguity and cryptic speciation of Hypotrigona species through Morphometrics and DNA barcoding
}

Nelly N Ndungu ${ }^{\mathrm{a}, \mathrm{b} *}$, Kiatoko Nkoba ${ }^{\mathrm{a}}$, Catherine L Sole ${ }^{\mathrm{b}}$, Christian WW Pirk ${ }^{\mathrm{b}}$, A Yusuf Abdullahi $^{\text {b }}$, Suresh K Raina ${ }^{a}$ and Daniel K Masiga ${ }^{a}$

${ }^{\mathrm{a}}$ International Centre of Insect Physiology and Ecology (icipe), Nairobi, Kenya; ${ }^{\mathrm{b}}$ Social Insects Research Group, Department of Zoology and Entomology University of Pretoria, Pretoria, South Africa

\begin{abstract}
Stingless bees are important pollinators of cultivated and wild plants contributing significantly to biodiversity and food security. Conserving pollinator plant interactions is essential to secure these ecosystems services. The use of morphological features in the identification of stingless bees in the genus Hypotrigona is extremely difficult due to many similarities among species resulting in taxonomic ambiguity. Here, both traditional morphometrics and DNA barcoding were applied as complementary tools for the identification of three Hypotrigona species: Hypotrigona gribodoi, $H$. ruspolii and $H$. araujoi. The study results show that morphometrics separates $H$. gribodoi and $H$. ruspolii from $H$. araujoi; however there is an overlap between $H$. gribodoi and $H$. ruspolii. On the other hand, DNA barcoding separates the three species. There was lower genetic distance between $H$. araujoi and $H$. gribodoi from Kakamega (1.4\%) than between $\mathrm{H}$. gribodoi collected from Kakamega and $H$. gribodoi from Mwingi (4.3\%). The high genetic distance or intraspecific distance within $H$. gribodoi strongly suggests cryptic speciation within this species, and that the $H$. gribodoi collected from Mwingi is a potentially new putative species. Thus the use of morphometrics and molecular taxonomic approaches (DNA barcoding) provide a convenient, robust and reliable way to identify Hypotrigona species. It also indicates the need for a thorough revision of $H$. gribodoi species.
\end{abstract}




\section{Introduction}

Stingless bees (Hymenoptera: Apidae: Meliponinae) are important pollinators of crops and wild plants (Heard, 1999; Kiatoko, Raina, Muli, \& Mueke, 2014; Slaa, S’ anchez Chavesb, Chaves, Malagodi-Braga, \& Hofstede, 2006) and are therefore a major compliment to honey bee pollination (Cortopassi-Laurino et al., 2006; Vanbergen, 2013). Furthermore, stingless bees have additional commercial features, which can be explored. Stingless bees produce honey that is different from that of honey bees due to its on average high moisture content, $31 \%$ and $20.2 \%$, respectively, the high water content is due to enzymes and other substances that are associated with antibiotic activity of the stingless bee honey (Lubertus, Bruijn, Martens, \& Sommeijer, 2006). Although stingless bee honey is produced in smaller quantities when compared to honey bees (Apis mellifera) (Kiatoko, Kumar, \& Langevelde, 2016), their honey fetches higher prices due to its medicinal value (Kumar, Singh, \& Alagumuthu, 2012). Stingless bee hive products include propolis and cerumen, all of which have been shown to have antioxidant activities (Pérez- Perez, Suárez, Pena_Vera, Gonzálvez, \& Vit, 2013); antibacterial and immunomodulatory effect (Liberio et al., 2011; Temaru \& Shimura, 2007); anti-inflammatory effects (Araujo, Libério, Guerra, Ribeiro, \& Nascimento, 2012); inhibit dermal carcinogenesis in rodents (Pereira-Filho et al., 2014) and thus could be utilized in medicine. These commercial opportunities, combined with their ability to pollinate important plants have led to an increased interest in their commercial cultivation. The exploitation is however limited by lack of basic biological knowledge and the ability to easily distinguish species. Furthermore, taxonomic clarity is paramount for understanding pollinator ecology, especially in understudied areas like Africa (Archer, Pirk, Carvalheiro, \& Nicolson, 2014).

Stingless bee species are grouped into two tribes: Trigonini and Meliponini that occur in Tropical and Neotropical regions of the world, respectively (Michener, 2000; Wille, 1983). They are differentiated from other bees by reduced sting and wing venation and the presence of penicillium on the hind tibiae (Eardley, 2004, Michener, 2007). However, the penicillium is absent or much reduced and soft in the genera Hypotrigona and Cleptotrigona (Eardley, 2004). In Africa, 19 species in six genera have been identified (Eardley 2004); these include Dactylurina Cockerell, 1934a, Meliponula Cockerell, 1934, Plebeina Moure, 1961a, Hypotrigona Cockerell, 1934a, Liotrigona Moure, 1961a and Cleptotrigona Moure, 1903 (Eardley, 2004). Cleptotrigona workers are known to rob pollen and nectar from other stingless 
bees while workers from the remaining genera collect their own food from wild flowers and commercial crops (Eardley, 2004). Hypotrigona, the focus of this study, contains four species, $H$. gribodoi, H. araujoi, H. ruspolii and H. penna, of which the last one occurs in West Africa.

African Stingless bees have been poorly studied, with the result that classification of the group is still largely unresolved (Eardley, 2004; Michener, 2000). Hypotrigona species are known to be especially difficult to identify due to the similarity in their body morphology (Eardley, 2004). Several studies have attempted to distinguish the three East African Hypotrigona species: for instance Guiglia (1955) described H. gribodoi morphologically; Michener (1959) confirmed through breeding experiment that $H$. araujoi and $H$. gribodoi could not mate and were indeed biological species. Moure (1961) separated H. gribodoi and H. araujoi based on whole body length ratio, and Eardley (2004) generated a taxonomic key in which he showed that the character differentiating the three Hypotrigona species is that in H. ruspolii there is an imaginary line posterior to midline of the hind tibia while in $H$. gribodoi and $H$. araujoi the line is in the middle. In addition, Eardley (2004) used the worker legs, wings, head and thorax to describe Hypotrigona species where, head and scutal vestiture weakly pinnate and scutal punctuation is slightly shiny. Despite these attempts to differentiate Hypotrigona species, it still remains difficult to identify these species without the expert taxonomic knowledge needed to interpret the keys. Tools that are easier to use are needed to differentiate between Hypotrigona species that can be applied both at a large scale and to varying levels of taxonomic expertise.

This study therefore combines morphometrics and DNA barcoding in an attempt to identify and differentiate the closely related species of Hypotrigona in Kenya. DNA barcoding tools have been used previously to identify bees; (Hurtado-Burillo, Ruiz, De Jesús May-Itzá, QuezadaEúan, \& De La Rúa, 2013; Magnacca \& Brown, 2012; Sheffield \& Hebert, 2009) and ants in the genus Solenopsis (Delsinne et al., 2016). A new species of sweat bee, Lasioglossum ephialtum (Gibbs) was described using DNA barcoding, in combination with geographical and morphological data (Gibbs \& Dumesh, 2013). Recently five stingless bee species in Kenya have been identified using morphometrics and DNA barcoding, revealing cryptic speciation within the Meliponula ferruginea reddish brown and black "morphospecies" (Ndungu et al., 2017). The 5' end of $\mathrm{COl}$ was chosen as the focal region because it is bordered by two universal primers that work for a wide range of metazoans (Hebert, Cywinska, Ball, \& deWaard, 2003; Puillandre et 
al., 2012) and has been shown to be most informative for species identification (Hajibabaei, Singer, Hebert, \& Hickey, 2007; Sheffield \& Hebert, 2009). The aims of this chapter therefore were to apply a DNA barcoding protocol based on the cytochrome c oxidase 1 (COI) gene sequence and morphometric analysis to identify the species of Hypotrigona.

\section{Methodology}

\section{Study sites}

Stingless bee samples were collected from 2014 to 2015 across two ecological zones in Kenya, namely Kakamega and Mwingi which are geographically distant and cover high and medium altitudes, respectively (Fig. 1.). Kakamega forest is a tropical rain forest in western Kenya (latitude $0^{\circ} 09^{\prime} \mathrm{N}$ to $0^{\circ} 22^{\prime} \mathrm{N}$ and longitude $34^{\circ} 50^{\prime} \mathrm{E}$ to $34^{\circ} 58^{\prime} \mathrm{E}$ ), supporting high biodiversity (Zimmerman, 1972) including bees (Kasina, Mburu, Kraemer, \& Holm-Mueller, 2009; Nkoba, Raina, Muli, Mithofer, \& Mueke, 2012). Mwingi is an arid to semi- arid region in eastern Kenya $\left(0^{\circ} 51^{\prime} \mathrm{S}, 38^{\circ} 22^{\prime} \mathrm{E}\right)$ that lies between 600 - $900 \mathrm{~m}$ above sea level (Njoroge, Kaibui, Njenga, \& Odhiambo, 2010).

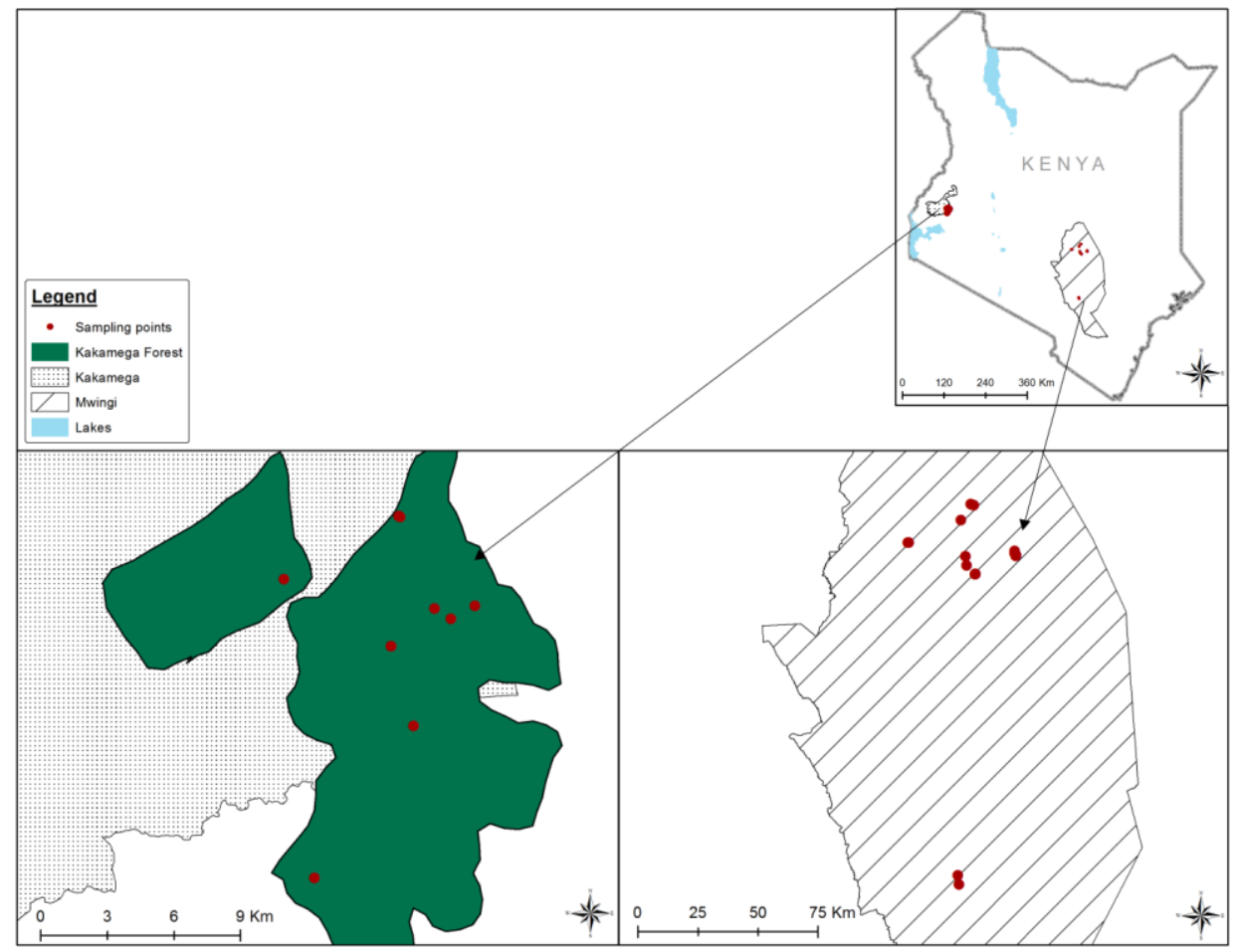

Fig. 1 Map of Kenya showing the two sampling areas, Kakamega forest (green) and Mwingi (chequered box). Circles represent all sampling points 


\section{Sampling method}

A total of 163 samples were collected for morphometric analysis. The number of sampled colonies varied across species and sites depending on availability as follows: $H$. ruspolii from Kakamega (17 colonies); H. araujoi from Kakamega (6 colonies); H. gribodoi from Mwingi (25 colonies) and H. gribodoi from Kakamega (26 colonies). As H. penna occurs in West Africa and could not be collected, this study only focuses on three of the species. The samples collected from both sites were used for morphometrics and DNA barcoding.

\section{Morphometrics}

Stingless bees were dissected under the microscope to remove the right forewing and right hind leg. The legs and wings were mounted on $2 \mathrm{~mm}$ slides and images taken using a Leica EZ4D stereomicroscope (Leica Microsystems Limited, Germany). Measurements were taken using the microscope accompanying software LAS EZ, version 1.4.0. Eight wing and three leg morphometric characters were selected for measurement in accordance with previous studies (Hartfelder \& Engels, 1992; J. Quezada-Euán et al., 2007). Each measurement was taken in triplicate (to an accuracy of $0.001 \mathrm{~mm}$ ). Measurements included forewing length (WL), forewing width (WW), distances between selected forewing veins, V3-V8, and tibia length (TL), tibia width (TW), and femur length (FL) (Fig. 2 A and B). Voucher specimens are preserved at the museum of the African Reference Laboratory for Bee Health icipe in Nairobi, Kenya. 


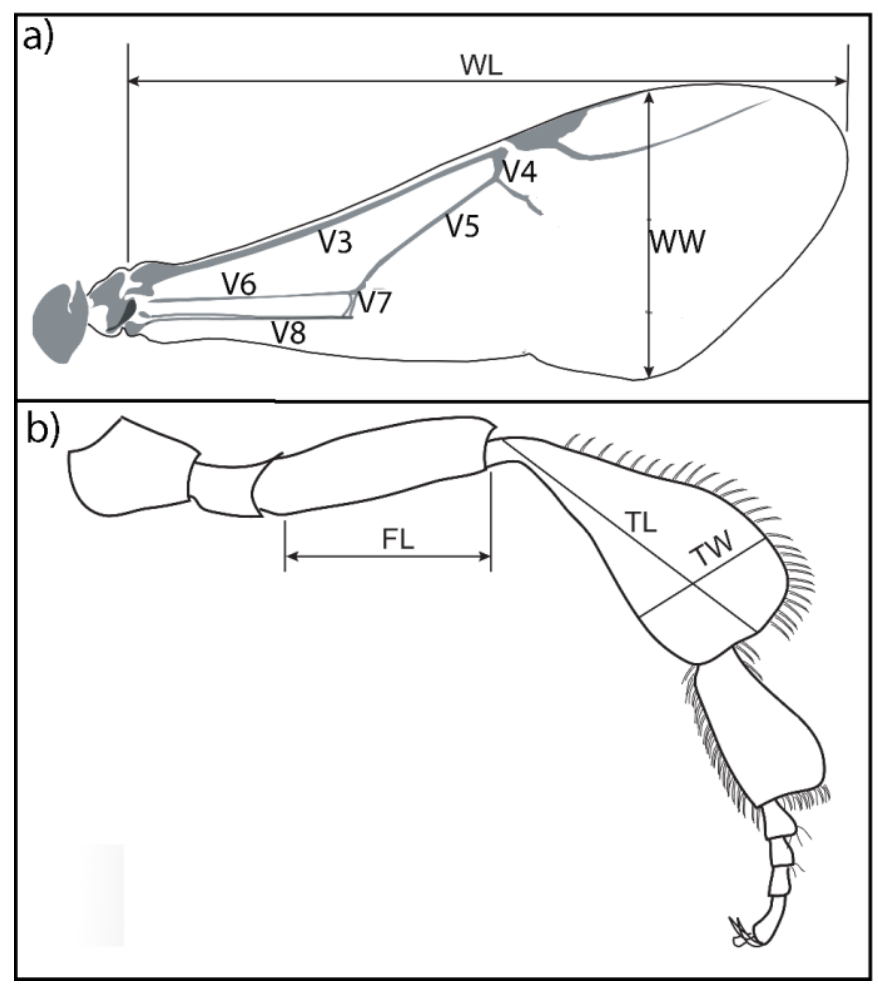

Fig. 2 Schematic representation of the right forewing and the right hind leg presenting morphometric characters of interest. (a) Right forewing showing veins used in morphometrics studies. WL= wing length; WW= wing width; V3= Marginal vein (R); V4= radial sector (RS); V5 = basal vein (M); V6= medial-cubital vein $(\mathrm{M}+\mathrm{Cu}) ; \mathrm{V} 7=$ cubitus $(\mathrm{Cu}) ; \mathrm{V} 8=\mathrm{V}$. (b) Right hind leg of a stingless bee. $\mathrm{FL}=$ femur length; $\mathrm{TL}=$ tibial length; $\mathrm{TW}=$ tibial width

\section{DNA extraction, amplification of the barcoding region and sequencing}

Genomic DNA was extracted from individual stingless bee legs using an Isolate II genomic DNA extraction Kit (Bioline) in a final elution volume of $30 \mu$ l. DNA barcoding procedure followed the Barcode of Life Database (BOLD) recommendations, thus we made sure that at least three DNA barcodes were sequenced to represent each species (Ratnasingham \& Hebert, 2007). The extracted DNA was stored at $-20{ }^{\circ} \mathrm{C}$ until required for amplification. The universal primer pair forward primer LCO1490 5'-GGTCAACAAATCATAAAGATATTGG-3' and reverse primer HCO2198 5'-TAAACTTCAGGGTGACCAAAAAATCA-3' (Folmer, Black, Hoeh, Lutz, \& Vrijenhoek, 1994) were subsequently used to amplify a 650 bp fragment of the COI gene. PCR was carried out in a total volume of $25 \mu \mathrm{l}$ containing 10 pmol of each primer, 10 $\mathrm{mM}$ Tris-Cl, $\mathrm{pH} 8.3$ and $50 \mathrm{mM} \mathrm{KCl}, 1.5 \mathrm{mM} \mathrm{MgCl} 2,2.5 \mathrm{mM}$ dNTPs, $2 \mu 1$ of $50 \mathrm{ng} / \mu 1 \mathrm{DNA}$ template and 1 unit of Taq DNA polymerase (Genscript Corp, Piscataway, NJ). PCR standard cycling conditions of $3 \mathrm{~min}$ at $94{ }^{\circ} \mathrm{C}$, then 35 cycles of 30s at $94{ }^{\circ} \mathrm{C}, 30$ s at $47{ }^{\circ} \mathrm{C}$ and 30s at 72 
${ }^{\circ} \mathrm{C}$, followed by a final elongation step of $10 \mathrm{~min}$ at $72{ }^{\circ} \mathrm{C}$ were used. The PCR products were visualized using ethidium bromide on a $1.2 \%$ agarose gel. The products were purified using QIAquick PCR purification kit (Qiagen, GmbH-Hilden, Germany) according to the manufacturer's instructions and subsequently sequenced bi-directionally using ABI 3700 genetic analyzer. The COI sequences were submitted to the Barcode of Life database (BOLD) and GenBank (Appendix I Table 1).

\section{Data Analyses Multivariate analyses of morphometrics}

Morphometric analyses were performed using R 3.2.1 (R Development Core Team, 2015). Principal Component Analysis (PCA), a multivariate method that does not assume a priori grouping of individuals was used to determine the clustering of different species. Data were log transformed $\left(\log _{10}\right)$ before analysis to conform to the assumptions of PCA (Keene, 1995). The first and second Eigen values were considered in the interpretation of the PCA output, as they were associated with the majority $(>70 \%)$ of the variation between samples. Character loadings were obtained for the first two principal components, to provide an indication of the influence of each character on the principal components. The first two principal component scores were plotted for forewing and leg measurements. The log-transformed data were also subjected to Canonical Variate Analysis (CVA) to analyze group structure in the multivariate data. In addition, Mahalanobis squared distances $\left(\mathrm{D}^{2}\right)$ between species were computed across morphometric characters. Mahalanobis squared distance $\left(\mathrm{D}^{2}\right)$ is a measure of divergence or distance between a pair of groups within the multivariate character space, in the presence of correlation among variables (Mahalanobis, 1936). Mahalanobis squared distance was calculated to complement PCA and CVA plots, and the genetic distances.

\section{Analysis of COI sequence data}

\section{BOLD Analysis Tools}

Barcode of Life Data systems (BOLD) workbench tools were used to generate various results that include: sequence base composition, diagnostic characters (differences in base pairs i.e. characters), Barcode gap analysis and distance summary (http://www.boldsystems.org/). To generate diagnostic characters, the sequences of Hypotrigona species were aligned using Muscle and the positions at which the nucleotides differ were used as diagnostic characters. The 
diagnostic character analysis provides a means to examine nucleotide polymorphism between consensus sequences of the Hypotrigona species and characterizes how unique the consensus bases are compared to the other consensus sequences. To determine the distribution of distances within each species and the distance to the nearest neighbor of each species, the Barcode Gap Analysis was done using Kimura-2 parameter distance model and MUSCLE (Edgar, 2004) alignment option. Barcode Gap analysis is the distance to the nearest neighbor for the species. Lastly, to report the sequence divergence between barcode sequences at the species level and within species divergence, distance summary was calculated using the BOLD tools (Ratnasingham \& Hebert, 2007).

\section{Phylogenetic Analyses}

Bioedit (Hall, 1999) was used to assemble and edit the sequences, and alignment done using Muscle, (Edgar, 2004), in MEGA 6 (Tamura, Stecher, Peterson, Filipski, \& Kumar, 2013) with default settings and then converted into Phylip format using Seaview (Gouy, Guindon, \& Gascuel, 2010). To view the separation of Hypotrigona species, phylogenetic trees were deduced using criteria for Maximum likelihood (ML) as implemented in RAxML v8.2.0 (Stamatakis, 2014) and neighbor-joining (NJ) as implemented in MEGA 6.

For ML analyses COI was assigned a GTR $+\mathrm{G}$ model and empirical base frequencies were estimated by the program, while for the $\mathrm{NJ}$ method p-distance was used to estimate the phylogeny. For both analyses node support was estimated by non-parametric bootstrap (Felsenstein, 1995) based on 1000 replicates. In addition, to calculate genetic distances, pairwise genetic distances (p-distance) within and between species were calculated in MEGA 6. Two Meliponula lendliana from the BOFAS project in BOLD were used as out groups (KU146611 and KU146608).

\section{Results}

\section{Morphometrics}

In the PCA plot, $H$. ruspolii separated completely from $H$. araujoi; however, $H$. gribodoi overlaps with $H$. ruspolii and $H$. araujoi. Hypotrigona gribodoi from Mwingi and $H$. gribodoi from Kakamega formed a single cluster. PC1 and PC2 contributed $64.4 \%$ and $13.4 \%$ respectively to the total variation in separation of the species (Fig. 3a). Tibia width and length showed the 
highest contribution in PCA 1 to the differentiation of the species ( 0.5 and 0.417 , respectively). Separation was greater in a CVA plot that sought to find maximal differences among a priori defined groups; CV1 and CV2 accounted for $78.9 \%$ and $16.7 \%$ of the variance in the data, respectively (Fig. 3b). Three clusters were formed; a) $H$. araujoi alone, b) $H$. gribodoi from Mwingi partially separated from $H$. gribodoi from Kakamega and c) H. ruspolii. Mahalanobis squared distance $\left(\mathrm{D}^{2}\right)$ shows that the largest distance is between $H$. araujoi and $H$. ruspolii (44.65), while the shortest distance was between $H$. gribodoi from Kakamega and $H$. gribodoi from Mwingi (9.47). Mahalanobis squared distance between $H$. araujoi and $H$. gribodoi from Kakamega was larger than $\mathrm{D}^{2}$ between $H$. araujoi and $H$. gribodoi from Mwingi (21.83 and $12.83)$, respectively.

(a)

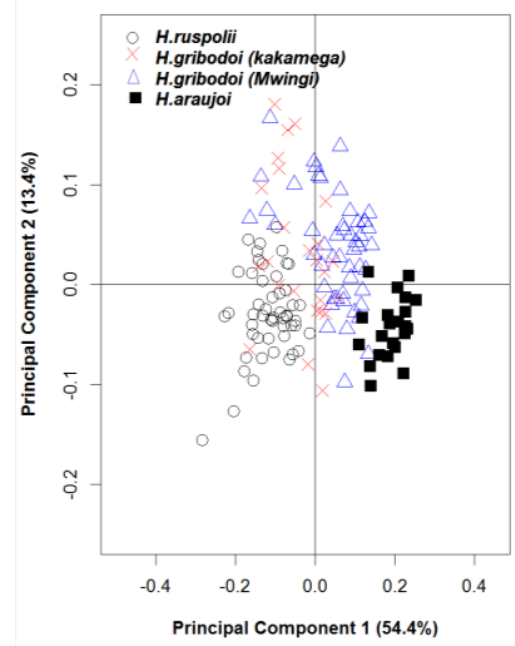

(b)

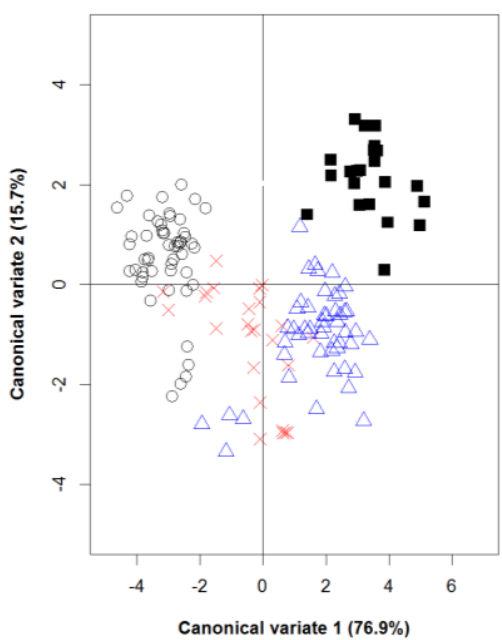

Fig. 3 Multivariate analyses of the wing morphometric measurements. (a). Principal component analysis (PCA) performed on Hypotrigona species. PC1 and PC2 contributed $67.8 \%(54.4 \%$ and $13.4 \%)$ respectively in the separation. There was partial separation of $H$. araujoi from $H$. gribodoi and H. ruspolii (b) Canonical variate analysis (CVA) performed on the complete dataset with the Hypotrigona species. CV1 and CV2 contributed 93.6\% to the separation (76.9\% and $16.7 \%$ ) respectively. Hypotrigona araujoi and H. ruspolii separate completely. There was an overlap between $H$. ruspolii and $H$. gribodoi from Kakamega 


\section{Analysis of COI sequences}

\section{BOLD Analysis}

Hypotrigona ruspolii had 25 diagnostic characters, while $H$. araujoi and $H$. gribodoi had 25 and 9 partial diagnostic characters, respectively (Fig. 4). In terms of Barcode Gap Analysis, the mean intraspecific distance within each species is $1.46 \pm 0.19 \%$ while mean distance to the Nearest Neighbor $(\mathrm{NN})$ is $2.67 \pm 1.04 \%$. The highest intraspecific distance was observed in $H$. gribodoi from Mwingi and $H$. gribodoi from Kakamega (5.41\%), followed by $H$. araujoi and $H$. ruspolii $2.66 \%$ and $2.51 \%$, respectively (Table 1 ). BOLD calculated genetic mean distance within species and the genus were $1.76 \%$ and $7.08 \%$, respectively.

Table 1. DNA Barcode Gap Analysis of the three Hypotrigona species

\begin{tabular}{ccccc}
\hline Species & $\begin{array}{c}\text { Mean } \\
\text { Intraspecific } \\
(\%)\end{array}$ & $\begin{array}{c}\text { Maximum } \\
\text { Intra } \\
\text { specific (\%) }\end{array}$ & $\begin{array}{c}\text { Nearest } \\
\text { Species }\end{array}$ & $\begin{array}{c}\text { Distance to } \\
\text { Nearest } \\
\text { Neighbor(NN) } \\
(\%)\end{array}$ \\
\hline $\begin{array}{l}\text { H. } \text { araujoi } \\
\text { H. }\end{array}$ & 1.76 & 2.66 & H. gribodoi & 0.46 \\
gribodoi & 1.95 & $5.41 *$ & H. araujoi & 0.46 \\
\hline H. ruspolii & 0.67 & 2.51 & H. gribodoi & 7.08 \\
\hline
\end{tabular}

Sequence divergence for all sequences compared at the species and genus level. * H. gribodoi from Kakamega and H. gribodoi, Mwingi combined 

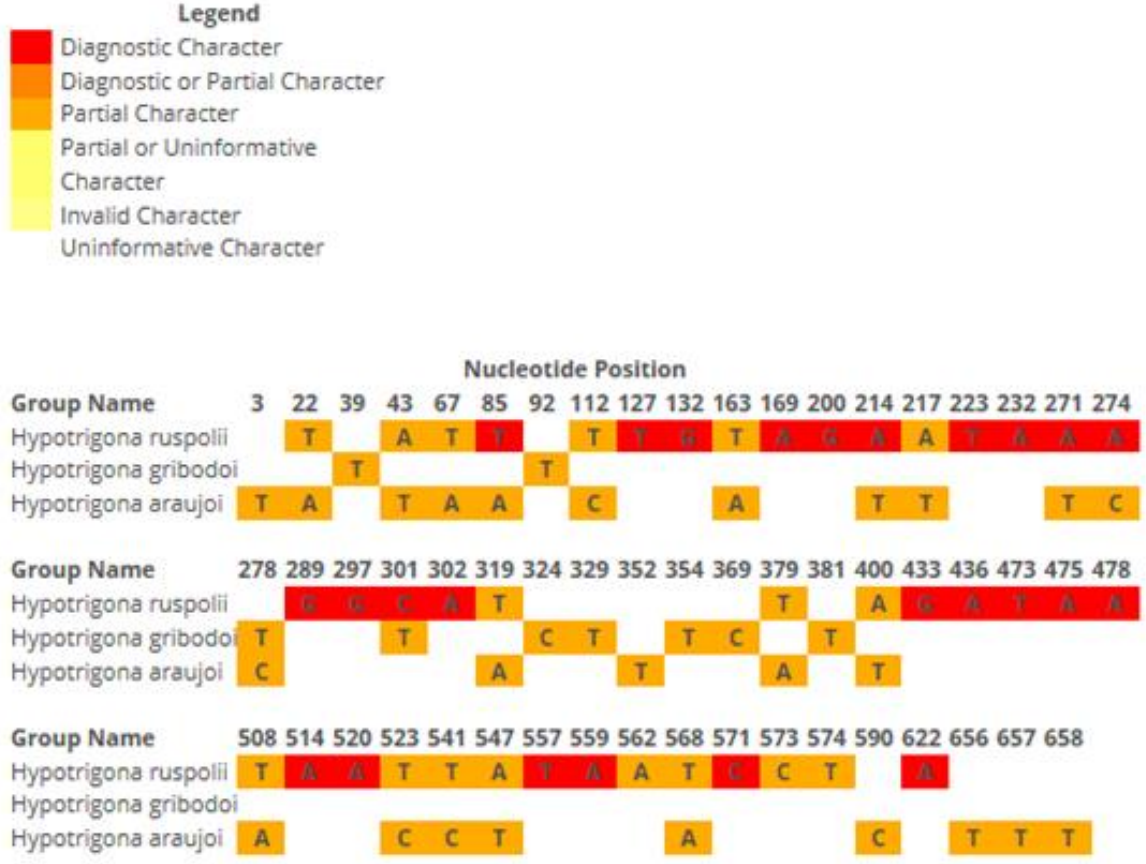

Fig. 4. Characters that differentiate H. gribodoi, H. ruspolii and H. araujoi, generated with BOLD analysis tools.

The Individual sequence length $=658$. No. groups in MSA with minimum 3 sequences $=3$. Legend: $*=$ diagnostic character; $\mathrm{P}=$ partial character. Hypotrigona ruspolii was the only species with specific diagnostic characters 25 and 17 partial diagnostic characters, while $H$. araujoi and H. gribodoi had 25 and 9 partial diagnostic characters respectively.

\section{Phylogenetic and distance analysis}

The maximum likelihood and Neighbor Joining methods supported the monophyly of Hypotrigona (99/100\% bootstrap support, respectively) (Fig. 5). Hypotrigona ruspolii is a wellsupported monophyletic species (99/100\% bootstrap support, respectively) and is sister to all the other species. H. gribodoi from Kakamega and H. araujoi form a paraphyletic clade (99/98\% bootstrap support, respectively) and are sister to H. gribodoi (Mwingi) (93/79\% bootstrap support, respectively). Hypotrigona gribodoi from Mwingi forms a monophyletic albeit poorly supported clade (58/-\% bootstrap support; respectively). Based on genetic distance, $H$. araujoi appears more closely related to $H$. gribodoi from Kakamega with a distance of 0.015 (1.5\%) and more distant from $H$. gribodoi from Mwingi at 0.061 (6.1\%). The distance between $H$. gribodoi from Mwingi and $H$. gribodoi from Kakamega was 0.043 (4.3\%). The highest genetic distance observed was between $H$. araujoi and $H$. ruspolii, 0.107 (10.7\%). The highest within group mean 


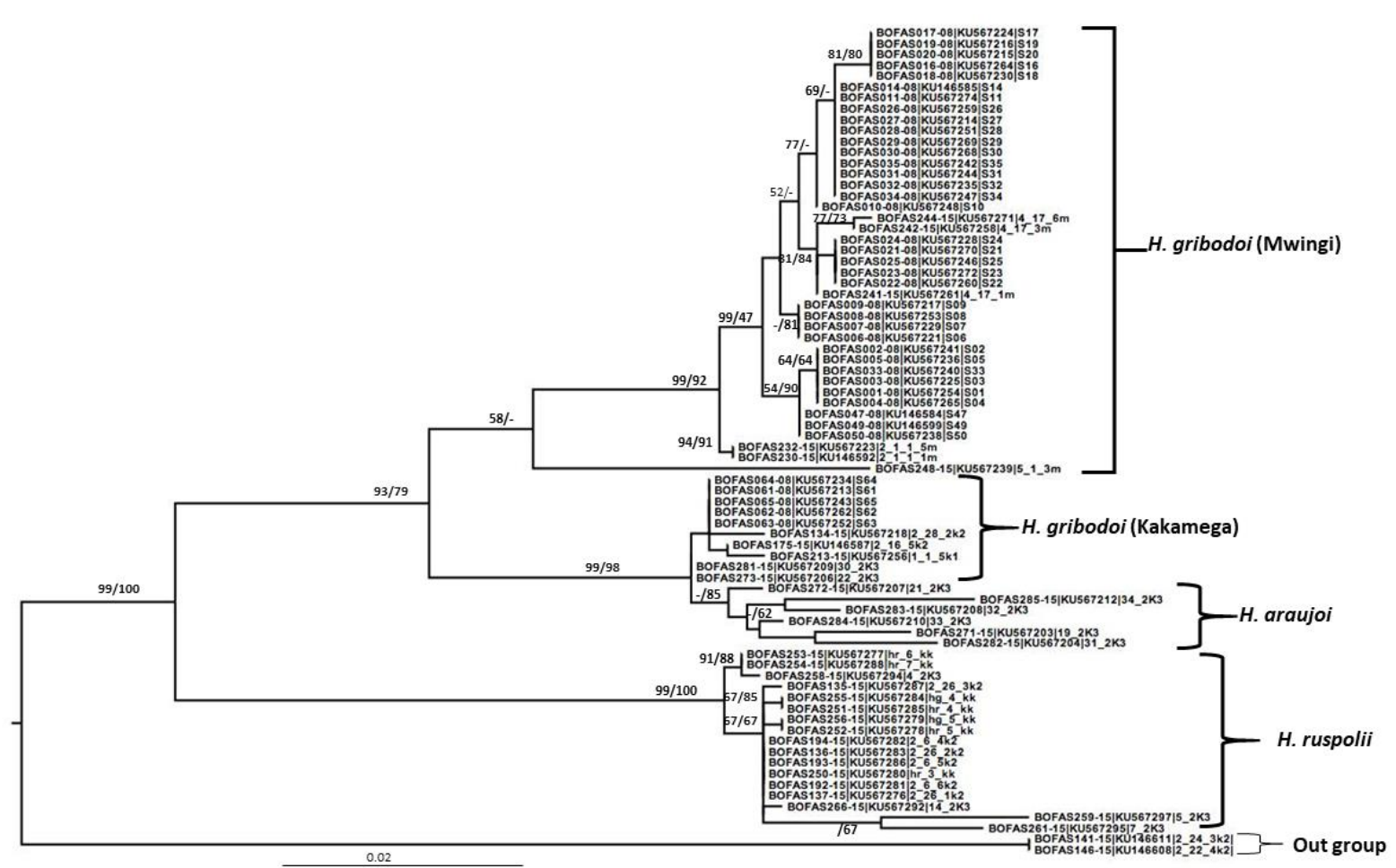

Fig. 5. RAxML phylogram, bootstrap values for both Maximum Likelihood (ML) and Neighbor-joining (NJ) analyses are displayed above the nodes (NJ/ML). Labels include the accession numbers of the BOFAS (Bees of the World-Africa - stingless bees) database which is part of BOLD (Barcode of Life database www.barcodinglife.org), GenBank Accession numbers and sample IDs 
distance was in $H$. araujoi at 0.017 (1.7\%), followed by $H$. gribodoi from Mwingi at $0.0084(8.4 \%)$ and lastly H. gribodoi from Kakamega at $0.0021(0.21 \%)$ (Fig 5).

\section{Discussion}

Morphometrics has been used in a number of studies aimed at differentiating species and races of honey bees (Apis mellifera) (Quezada-Euán et al., 2011; Raina \& Kimbu, 2005) and bumblebees (Owen, 2009). Hypotrigona gribodoi from Kakamega overlaps with H. ruspolii and H. gribodoi from Mwingi (Fig. 3a and b). Overlap is expected since Hypotrigona species are very similar in morphological features and all have a small body size ( 2mm) (Eardley 2004).

Reduced and weak wing venation were observed in all Hypotrigona species, a characteristic common in stingless bees (Wille, 1983). The results show that tibia width and length showed the highest contribution to the differentiation of the species. These results are supported by Eardley (2004), where H. ruspolii was shown to have the smallest tibia in terms of width amongst the Hypotrigona species (Eardley, 2004). These results corroborate a previous study where $H$. araujoi had been shown to have a wider tibia compared to H. gribodoi ( (Michener, 1959). In addition, Eardley (2004) also reported that $H$ araujoi is the largest of the Hypotrigona species while $H$. ruspolii is the smallest in terms of body size. Therefore, tibial length and width can be used to differentiate $H$. ruspolii and $H$. araujoi.

DNA barcoding results contrast with those of the morphometric analyses as H. ruspolii is a wellsupported monophyletic clade separate from $H$. gribodoi and $H$. araujoi. There are 25 diagnostic characters that can be used efficiently to separate $H$. ruspolii from other Hypotrigona species. The separation of $H$. ruspolii from $H$. araujoi in the CVA plots is supported by DNA barcoding results where the two separate with the highest genetic distance $(10.3 \%)$. Thus, there is a strong indication that $H$. ruspolii is genetically distant from the other Hypotrigona species. On the other hand, only partial diagnostic characters were observed for $H$. gribodoi and $H$. araujoi thus the two species are more difficult to differentiate within the Hypotrigona species.

In addition, there was lower interspecifc distance between $H$. araujoi and $H$. gribodoi from Kakamega when compared to $H$. gribodoi from Mwingi and $H$. gribodoi from Kakamega. Hypotrigona gribodoi collected from Kakamega forms a paraphyletic clade with $H$. araujoi and therefore appears more closely related than $H$. gribodoi from Mwingi and Kakamega. Hypotrigona gribodoi and $H$. araujoi were previously considered a single species due to high 
morphological similarity. However, Araujoi and Kerr (1959) in their study in Luanda, Angola, reported that $H$. gribodoi and $H$. araujoi do not interbreed and are thus different species. In addition to this they differ in nest architecture, cluster arrangement and horizontal combs. Araujo and Kerr (1959) termed $H$. gribodoi and $H$. araujoi as cryptic or sibling species, which is evident from the molecular data for samples collected in Kakamega Forest (Fig. 5). Such results have been observed in butterflies where closely related but morphologically and ecologically distinct species differed by only one to three nucleotides (Burns, Janzen, Hajibabaei, Hallwachs, \& Herbert, 2007). The high intraspecific variation within H. gribodoi from Mwingi and $H$. gribodoi from Kakamega could be a result of adaptation to different environments and they may represent independent evolutionary units. Such high genetic distance was found in a stingless bee Plebeia remota where the samples were collected from two different localities in Brazil whose ecological characteristics differed significantly and, thus, it was suggested that paleogographic and paleoclimatic events led to isolation of the two populations (Cristina, Magalhães, \& Oliveira, 2006). The morphometric-based PCA and CVA analyses revealed an overlap and partial separation of $H$. gribodoi from Mwingi and H. gribodoi from Kakamega; thus, in terms of size, we suggest that the two represent different species that are cryptic (i.e. morphologically indistinguishable).

DNA barcoding separated the three Hypotrigona species completely and can therefore be reliably used for species identification. The low genetic distance between $H$. araujoi and $H$. gribodoi from Kakamega shows that the two species are closely related. However, using mophometric tools, the two species separated completely in the CVA. The results indicate the need for integration of morphometrics and DNA barcoding. Integration of morphometric and DNA barcoding tools have been used in a study of the stingless bee Melipona yucatanica to detect cryptic speciation (May-Itzá, Quezada-Euán, Medina, Enríquez, \& de la Rúa, 2010), to resolve the taxonomy of western Malagasy stingless bee Liotrigona moure (Koch, 2010) and for the differentiation in the Neotropical bee Melipona beechii (Quezada-Euán et al., 2007). Reliable identification requires combining DNA barcoding and the morphometrics as tools for differentiating the three Hypotrigona species.

The data suggest a likelihood of cryptic speciation within $H$. gribodoi species and thus a potentially new putative species of $H$. gribodoi collected from Mwingi. Mwingi and Kakamega are highly diverse in terms of climatic conditions and geographic distance, potential reasons for 
high intraspecific genetic distances observed (Cristina et al., 2006). Kakamega forest is located in the highlands of western Kenya and is a tropical rainforest that lies between $1500-1600 \mathrm{~m}$ above sea level (Tsingalia \& Kassily, 2009) with an average annual rainfall of $1200-1700 \mathrm{~mm}$. Mwingi, on the other hand, is a mid-altitude and semi- arid area that lies between $600-900 \mathrm{~m}$ above sea level (Njoroge et al., 2010). The climate is hot and dry across most of the year with an average annual rainfall of $400-800 \mathrm{~mm}$ and temperatures that vary throughout the year, ranging between $24-34^{\circ} \mathrm{C}$ (Njoroge et al., 2010; Opiyo, Mureithi, \& Ngugi, 2011). Large areas are occupied by grasslands and shrubs, mainly consisting of dry land vegetation (Kaloi, Tayebwa, \& Bashaasha, 2005).

The H. gribodoi populations in Mwingi and Kakamega are isolated by a large geographical distance of approximately $500 \mathrm{~km}$ which includes the Great Rift Valley (https://en.wikipedia.org/wiki/Great_Rift_Valley, _Kenya) and thus interbreeding between these two H. gribodoi populations is unlikely. A study carried out on Melipona subtinida showed high intraspecifc variation, which was taken as an evidence of isolation (Cruz et al., 2006). It has been suggested that stingless bees migrate for short distances of about fifty to few hundred meters between conspecific colonies (Roubik, 2006). More specifically, Hypotrigona species mate about 100m around their nests (Portugal-Araujo \& Kerr, 1959) and they are known to forage across short distances of about 300m (Wille, 1983).

In conclusion, integration of morphometrics and DNA barcoding has successfully identified and differentiated the three Hypotrigona species. The study suggests adopting DNA barcoding and morphometrics to identify Hypotrigona species. The high genetic distance or intraspecific distance within $H$. gribodoi suggests the possibility of cryptic speciation and thus a potentially new putative species should be described. Additional 


\section{References}

Araujo, M., Libério, S., Guerra, R., Ribeiro, S., \& Nascimento, F. (2012). Mechanisms of action underlying the anti- infl ammatory and immunomodulatory effects of propolis : a brief review. Brazilian Journal of Pharmacognosy, 22(1), 208-219. http://doi.org/10.1590/S0102-695X2011005000167

Archer, C. R., Pirk, C. W. W., Carvalheiro, L. G., \& Nicolson, S. W. (2014). Economic and ecological implications of geographic bias in pollinator ecology in the light of pollinator declines. Oikos, 123(4), 401-407. http://doi.org/10.1111/j.1600-0706.2013.00949.x

Burns, J. M., Janzen, D. H., Hajibabaei, M., Hallwachs, W., \& Herbert, P. (2007). DNA barcodes of closely related (but morphologically and ecologically distinct) species of skipper butterflies (Hesperiidae) can differ by only one to three. Journal of the Lepidopterists Society, 61(3), 138-153.

Cortopassi-Laurino, M., Imperatriz-Fonseca, V. L., Roubik, D. W., Dollin, A., Heard, T. A., Aguilar, I., Venturieri, G. C., Erdley, C. \& Nogueira-Neto, P. (2006). Global meliponiculture: challenges and opportunities. Apidologie, 37(2), 275-292. http://doi.org/10.1051/apido:2006027

Cristina, A. M., Magalhães, R., \& Oliveira, F. F. de. (2006). Molecular markers as a tool for population and evolutionary studies of stingless bees. Apidologie, 37, 259-274. http://doi.org/10.1051/apido:2006021

Cruz, D. de O., Jorge, D., Periera, J., Torres, D., Soares, C. E., Freitas, B., \& Grangeiro, B. (2006). Intraspecific variation in the first Internal Transcribed Spacer 1 (ITS1) of the nuclear ribosomal DNA in Melipona subnitida (Hymenoptera, Apidae), an endemic stingless bee from northeastern Brazil. Apidologie, 37, 376-386. http://doi.org/DOI: 10.1051/apido:2006003

Delsinne, T. C., Sonet, G., Nagy, Z. T., Wauters, N., Jacquemin, J., \& Leponce, M. (2016). High species turnover of the ant genus Solenopsis ( Hymenoptera : Formicidae) along an altitudinal gradient in the Ecuadorian Andes, indicated by a combined DNA sequencing and morphological approach. Invertebrate Systematics, 26, 457-469. http://doi.org/10.1071/IS12030

Eardley, C. D. (2004). Taxonomic revision of the African stingless bees (Apoidea: Apidae: Apinae: Meliponini). African Plant Protection, 10(2), 63-96.

Edgar, R. C. (2004). MUSCLE: Multiple sequence alignment with high accuracy and high throughput. Nucleic Acids Research, 32(5), 1792-1797. http://doi.org/10.1093/nar/gkh340

Folmer, O., Black, M., Hoeh, R., Lutz, R., \& Vrijenhoek, R. (1994). DNA primers for amplification of mitochondrial cytochrome c oxidase subunit I from diverse metazoan invertebrates. Molecular Marine Biology and Biotechnology, 3(5), 294-299.

Gibbs, J., \& Dumesh, S. (2013). A new species, Lasioglossum (Eickwortia) hienae, from Mexico (Apoidea: Halictidae). Journal of Melittology, 13, 1-11. 
Gouy, M., Guindon, S., \& Gascuel, O. (2010). SeaView version 4: A multiplatform graphical user interface for sequence alignment and phylogenetic tree building. Molecular Biology and Evolution, 27(2), 221-224. http://doi.org/10.1093/molbev/msp259

Hajibabaei, M., Singer, G., Hebert, P., \& Hickey, D. (2007). DNA barcoding: how it complements taxonomy, molecular phylogenetics and population genetics. TRENDS in Genetics, 23(4), 167-172. http://doi.org/10.1016/j.tig.2007.02.001

Hall, T. (1999). BioEdit: a user-friendly biological sequence alignment editor and analysis program for Windows 95/98/NT. Nucleic Acids Symposium Series. http://doi.org/citeulikearticle-id:691774

Hartfelder, K., \& Engels, W. (1992). Allometric and multivariate analysis of sex and caste polymorphism in the neotropical stingless bee, Scaptotrigona postica. Insectes Sociaux, 39(3), 251-266. http://doi.org/10.1007/BF01323946

Heard, T. A. T. (1999). The role of stingless bees in crop pollination. Annual Review of Entomology, 44(131), 183-206. http://doi.org/10.1146/annurev.ento.44.1.183

Hebert, P. D. N., Cywinska, A., Ball, S. L., \& deWaard, J. R. (2003). Biological identifications through DNA barcodes. Proceedings of the Royal Society B: Biological Sciences, 270(1512), 313-21. http://doi.org/10.1098/rspb.2002.2218

Hurtado-Burillo, M., Ruiz, C., De Jesús May-Itzá, W., Quezada-Eúan, J. J. G., \& De La Rúa, P. (2013). Barcoding stingless bees: Genetic diversity of the economically important genus Scaptotrigona in Mesoamerica. Apidologie, 44(1), 1-10. http://doi.org/10.1007/s13592-0120146-9

Kaloi, E., Tayebwa, B., \& Bashaasha, B. (2005). Food security status of households in Mwingi District, Kenya. African Crop Science Conference Proceedings, 7, 867-873.

Kasina, J. M., Mburu, J., Kraemer, M., \& Holm-Mueller, K. (2009). Economic benefit of crop pollination by bees: a case of Kakamega small-holder farming in western Kenya. Journal of Economic Entomology, 102(2), 467-473. http://doi.org/10.1603/029.102.0201

Keene, O. N. (1995). The log transformation is special. Statistics in Medicine, 14(8), 811-819. http://doi.org/10.1002/sim.4780140810

Kiatoko, N., Kumar, R. S., \& Langevelde, F. (2016). A vertical compartmented hive design for reducing post-harvest colony losses in three afrotropical stingless bee species (APIDAE: MELIPONINAE). International Journal of Development Research, 6(8), 9026-9034.

Kiatoko, N., Raina, S. K. S., Muli, E., \& Mueke, J. (2014). Enhancement of fruit quality in Capsicum annum through pollination by Hypotrigona gribodoi in Kakamega, Western Kenya. Entomological Science, 17, 106-110. http://doi.org/10.1111/ens.12030

Koch, H. (2010). Combining morphology and DNA barcoding resolves the taxonomy of western Malagasy Liotrigona Moure, 1961 (Hymenoptera: Apidae: Meliponini). African Invertebrates, 51(2), 413-421. 
Kumar, S. M., Singh, R. A. J. A., \& Alagumuthu, G. (2012). Traditional beekeeping of stingless bee (Trigona sp) by Kani tribes of Western Ghats, Tamil Nadu, India. Indian Journal of Traditional Knowledge, 11(2), 342-345.

Liberio, S., Pereira, A., Dutra, R., Reis, A., Araujo, A., NS, Mattar, L., Ribeiro, M., Nascimento, F., Guera, R., \& Monteiro-Neto, V. (2011). Antimicrobial activity against oral pathogens and immunomodulatory effects and toxicity of geopropolis produced by the stingless bee Melipona fasciculata Smith. BMC Complementary and Alternative Medicine, 11, 1-10.

Lubertus, B., Bruijn, L. L. M. De, Martens, E., \& Sommeijer, M. (2006). Original article Water content of stingless bee honeys (Apidae, Meliponini ): interspecific variation and comparison with honey of Apis mellifera. Apidologie, 37, 480-486.

Magnacca, K. K. N. K., \& Brown, M. J. F. M. (2012). DNA barcoding a regional fauna: Irish solitary bees. Molecular Ecology Resources, 12(6), 990-998. http://doi.org/10.1111/17550998.12001

Mahalanobis, P. C. (1936). On the generalized distance in statistics. Proceedings of the National Institute of Sciences, 2, 49-55. http://doi.org/10.1145/1390156.1390302

May-Itzá, W., Quezada-Euán, J. J., Medina, L., Enríquez, E., \& de la Rúa, P. (2010). Morphometric and genetic differentiation in isolated populations of the endangered Mesoamerican stingless bee Melipona yucatanica (Hymenoptera: Apoidea) suggest the existence of a two species complex. Conservation Genetics, 11, 2079-2084. http://doi.org/10.1007/s10592-010-0087-7

Michener, C. (2000). The bees of the world (1st ed.). The Johns Hopkins University Press, Baltimore, Maryland.

Michener, C. D. (1959). Sibling species of Trigona from Angola (Hymenoptera, Apinae). American Museum Novitates, 1956, 1-5.

Ndungu, N., Nkoba, K., Ciosi, M., Salifu, D., Nyansera, D., Masiga, D., \& Suresh, R. K. (n.d.). Identification of stingless bees (Hymenoptera: Apidae) in Kenya using morphometrics and DNA barcoding. Journal of Apicultural Research. http://doi.org/http://dx.doi.org/10.1080/00218839.2017.1327939 .

Njoroge, G. N., Kaibui, I. M., Njenga, P. K., \& Odhiambo, P. O. (2010). Utilisation of priority traditional medicinal plants and local people's knowledge on their conservation status in arid lands of Kenya (Mwingi District). Journal of Ethnobiology and Ethnomedicine, 6(22), 2-8. http://doi.org/10.1186/1746-4269-6-22

Nkoba, K., Raina, S. K., Muli, E., Mithofer, K., \& Mueke, J. (2012). Species richness and nest dispersion of some tropical meliponine bees (Apidae: Meliponinae) in six habitat types in the Kakamega forest, western Kenya. International Journal of Tropical Insect Science, 32(4), 194-202. http://doi.org/10.1017/S1742758412000355

Opiyo, F. E. O., Mureithi, S. M., \& Ngugi, R. K. (2011). The Influence of water availability on pastoralist's resource use in Mwingi and Kitui districts in Kenya. Journal of Human 
Ecology, 35(1), 43-52.

Owen, R. (2009). Applications of morphometrics to the Hymenoptera, particularly bumble bees (Bombus, Apidae). In P. C. W. (Ed.), Morphometrics (pp. 1-30).

Pereira-Filho, R., Batista, F., Ribeiro, R., de Melo, G., Reis, F., de Melo, A., Gomes, M., Cardoso, J \& Albuquerque, R. (2014). Chemopreventive effect of Brazilian green propolis on experimental dermal carcinogenesis in murine Model. International Journal of Morphology, 32(2), 522-530.

Pérez- Perez, E., Suárez, E., Pena_Vera, M., Gonzálvez, A., \& Vit, P. (2013). Antioxidant activity of nest products of Tetragonisca angustula from Mérida, Venezuela. In Stingless bees process honey and pollen in cerumen pots (pp. 1-8).

Portugal-Araujo, V. De, \& Kerr, W. E. (1959). A case of sibling species among social bees. Brazilian Journal of Biology, 19(3), 223-228.

Puillandre, N., Lambert, A., Brouillet, S., Achaz, G., Syste, D., \& Cuvier, R. (2012). ABGD, Automatic Barcode Gap Discovery for primary species delimitation. Molecular Ecology, 21(8), 1864-1877. http://doi.org/10.1111/j.1365-294X.2011.05239.x

Quezada-Euán, J. J. G., López-Velasco, A., Pe'rez-Balam, J., Moo-Valle, H., VelazquezMadrazo, A. \& Paxton, R. J. (2011). Body size differs in workers produced across time and is associated with variation in the quantity and composition of larval food in Nannotrigona perilampoides (Hymenoptera, Meliponini). Insectes Sociaux, 58(1), 31-38. http://doi.org/10.1007/s00040-010-0113-2

Quezada-Euán, J., Paxton, R. J. R., Palmer, K. A. K., May Itza, W., Tay, W \& Oldroyd, B. P. (2007). Morphological and molecular characters reveal differentiation in a Neotropical social bee, Melipona beecheii (Apidae: Meliponini). Apidologie, 38(3), 247-258. http://doi.org/10.1051/apido:2007006

R Core Team. (2015). R: A language and environment for statistical computing. R Foundation for Statistical Computing, Vienna, Austria. http://doi.org/10.1017/CBO9781107415324.004

Raina, S. K., \& Kimbu, D. M. (2005). Variations in races of the honeybee Apis mellifera (Hymenoptera: Apidae) in Kenya. International Journal of Tropical Insect Science, 25(4), 281-291. http://doi.org/10.1079/IJT200588

Ratnasingham, S., \& Hebert, P. D. N. (2007). BOLD : The Barcode of Life Data System (www.barcodinglife.org). Molecular Ecology Notes, 7(April 2016), 355-364. http://doi.org/10.1111/j.1471-8286.2006.01678.x

Roubik, D. W. (2006). Stingless bee nesting biology. Apidologie, 37(2), 124-143. http://doi.org/10.1051/apido:2006026

Sheffield, C., \& Hebert, P. (2009). DNA barcoding a regional bee (Hymenoptera: Apoidea) fauna and its potential for ecological studies. Molecular Ecology Resources, 9, 196-207.

Slaa, E. J., S’ anchez Chavesb, Chaves, L. A., Malagodi-Braga, K. S., \& Hofstede, F. F. E. 
(2006). Stingless bees in applied pollination : practice and perspectives. Apidologie, 37(2), 293-315. http://doi.org/10.1051/apido:2006022

Stamatakis, A. (2014). RAxML version 8: A tool for phylogenetic analysis and post-analysis of large phylogenies. Bioinformatics, 30(9), 1312-1313.

http://doi.org/10.1093/bioinformatics/btu033

Tamura, K., Stecher, G., Peterson, D., Filipski, A., \& Kumar, S. (2013). MEGA 6: Molecular evolutionary genetics analysis version 6.0. Molecular Biology and Evolution, 30(12), 27252729. http://doi.org/10.1093/molbev/mst197

Temaru, E., \& Shimura, S. (2007). Antibacterial activity of honey from stingless honeybees (Hymenoptera; Apidae; Meliponinae). Polish Journal of Microbiology, 56(4), 281-285.

Tsingalia, H. M., \& Kassily, F. N. (2009). The origins Kakamega Forest Grasslands: A Critical Review. Journal of Human Ecology, 27(2), 129-135.

Vanbergen, A. J. (2013). Threats to an ecosystem service: Pressures on pollinators. Frontiers in Ecology and the Environment, 11(5), 251-259. http://doi.org/10.1890/120126

Wille, A. (1983). Biology of the Stingless bees. Annual Review of Entomology, 28(1), 41-64. http://doi.org/10.1146/annurev.en.28.010183.000353

Zimmerman, D. A. (1972). The avifauna of the Kakamega Forest, western Kenya, including a abird population study. Bulletin of the American Museum of Natural History, 149(3), 255340. http://doi.org/10.1007/s13398-014-0173-7.2 


\section{APPENDIX I}

Table 1. BOLD, Sample ID and GenBank Accession numbers for all the samples used in this work

\begin{tabular}{|c|c|c|c|}
\hline Identification & BOLD & Sample ID & $\begin{array}{r}\text { GenBank } \\
\text { Accession }\end{array}$ \\
\hline Hypotrigona araujoi & BOFAS282-15 & 31_2K3 & KU567204 \\
\hline Hypotrigona araujoi & BOFAS272-15 & 21_2K3 & KU567207 \\
\hline Hypotrigona araujoi & BOFAS285-15 & 34_2K3 & KU567212 \\
\hline Hypotrigona araujoi & BOFAS284-15 & 33_2K3 & KU567210 \\
\hline Hypotrigona araujoi & BOFAS283-15 & 32_2K3 & KU567208 \\
\hline Hypotrigona araujoi & BOFAS271-15 & 19_2K3 & KU567203 \\
\hline Hypotrigona gribodoi & BOFAS281-15 & 30_2K3 & KU567209 \\
\hline Hypotrigona gribodoi & BOFAS049-08 & S49 & KU146599 \\
\hline Hypotrigona gribodoi & BOFAS230-15 & 2_1_1_1m & KU146592 \\
\hline Hypotrigona gribodoi & BOFAS047-08 & S47 & KU146584 \\
\hline Hypotrigona gribodoi & BOFAS014-08 & S14 & KU146585 \\
\hline Hypotrigona gribodoi & BOFAS175-15 & $2 \_16 \_5 \mathrm{k} 2$ & KU146587 \\
\hline Hypotrigona gribodoi & BOFAS273-15 & 22_2K3 & KU567206 \\
\hline Hypotrigona gribodoi & BOFAS244-15 & 4_17_6m & KU567271 \\
\hline Hypotrigona gribodoi & BOFAS023-08 & $\mathrm{S} 23$ & KU567272 \\
\hline Hypotrigona gribodoi & BOFAS011-08 & S11 & KU567274 \\
\hline Hypotrigona gribodoi & BOFAS061-08 & S61 & KU567213 \\
\hline Hypotrigona gribodoi & BOFAS027-08 & S27 & KU567214 \\
\hline Hypotrigona gribodoi & BOFAS020-08 & S20 & KU567215 \\
\hline Hypotrigona gribodoi & BOFAS019-08 & S19 & KU567216 \\
\hline Hypotrigona gribodoi & BOFAS009-08 & S09 & KU567217 \\
\hline Hypotrigona gribodoi & BOFAS134-15 & 2_28_2k2 & KU567218 \\
\hline Hypotrigona gribodoi & BOFAS006-08 & S06 & KU567221 \\
\hline Hypotrigona gribodoi & BOFAS232-15 & 2_1_1_5m & KU567223 \\
\hline Hypotrigona gribodoi & BOFAS017-08 & S17 & KU567224 \\
\hline Hypotrigona gribodoi & BOFAS003-08 & S03 & KU567225 \\
\hline Hypotrigona gribodoi & BOFAS024-08 & S24 & KU567228 \\
\hline Hypotrigona gribodoi & BOFAS007-08 & S07 & KU567229 \\
\hline Hypotrigona gribodoi & BOFAS018-08 & S18 & KU567230 \\
\hline Hypotrigona gribodoi & BOFAS064-08 & S64 & KU567234 \\
\hline Hypotrigona gribodoi & BOFAS032-08 & S32 & KU567235 \\
\hline Hypotrigona gribodoi & BOFAS005-08 & S05 & KU567236 \\
\hline Hypotrigona gribodoi & BOFAS050-08 & S50 & KU567238 \\
\hline Hypotrigona gribodoi & BOFAS248-15 & 5_1_3m & KU567239 \\
\hline Hypotrigona gribodoi & BOFAS033-08 & S33 & KU567240 \\
\hline Hypotrigona gribodoi & BOFAS002-08 & S02 & KU567241 \\
\hline Hypotrigona gribodoi & BOFAS035-08 & S35 & KU567242 \\
\hline Hypotrigona gribodoi & BOFAS065-08 & S65 & KU567243 \\
\hline Hypotrigona gribodoi & BOFAS031-08 & S31 & KU567244 \\
\hline Hypotrigona gribodoi & BOFAS025-08 & $\mathrm{S} 25$ & KU567246 \\
\hline Hypotrigona gribodoi & BOFAS034-08 & S34 & KU567247 \\
\hline Hypotrigona gribodoi & BOFAS010-08 & S10 & KU567248 \\
\hline Hypotrigona gribodoi & BOFAS028-08 & $\mathrm{S} 28$ & KU567251 \\
\hline Hypotrigona gribodoi & BOFAS063-08 & S63 & KU567252 \\
\hline Hypotrigona gribodoi & BOFAS008-08 & S08 & KU567253 \\
\hline
\end{tabular}




\begin{tabular}{|c|c|c|c|}
\hline Hypotrigona gribodoi & BOFAS001-08 & S01 & KU567254 \\
\hline Hypotrigona gribodoi & BOFAS213-15 & 1_1_5k1 & KU567256 \\
\hline Hypotrigona gribodoi & BOFAS242-15 & 4_17_3m & KU567258 \\
\hline Hypotrigona gribodoi & BOFAS026-08 & S26 & KU567259 \\
\hline Hypotrigona gribodoi & BOFAS022-08 & S22 & KU567260 \\
\hline Hypotrigona gribodoi & BOFAS241-15 & 4_17_1m & KU567261 \\
\hline Hypotrigona gribodoi & BOFAS062-08 & S62 & KU567262 \\
\hline Hypotrigona gribodoi & BOFAS016-08 & S16 & KU567264 \\
\hline Hypotrigona gribodoi & BOFAS004-08 & S04 & KU567265 \\
\hline Hypotrigona gribodoi & BOFAS030-08 & S30 & KU567268 \\
\hline Hypotrigona gribodoi & BOFAS029-08 & S29 & KU567269 \\
\hline Hypotrigona gribodoi & BOFAS021-08 & S21 & KU567270 \\
\hline Hypotrigona ruspolii & BOFAS135-15 & $2 \_26 \_3 \mathrm{k} 2$ & KU567287 \\
\hline Hypotrigona ruspolii & BOFAS137-15 & 2_26_1k2 & KU567276 \\
\hline Hypotrigona ruspolii & BOFAS192-15 & 2_6_6k2 & KU567281 \\
\hline Hypotrigona ruspolii & BOFAS136-15 & $2 \_26 \_2 \mathrm{k} 2$ & KU567283 \\
\hline Hypotrigona ruspolii & BOFAS193-15 & $2 \_6 \_5 \mathrm{k} 2$ & KU567286 \\
\hline Hypotrigona ruspolii & BOFAS251-15 & hr_4_kk & KU567285 \\
\hline Hypotrigona ruspolii & BOFAS250-15 & hr_3_kk & KU567280 \\
\hline Hypotrigona ruspolii & BOFAS254-15 & hr_7_kk & KU567288 \\
\hline Hypotrigona ruspolii & BOFAS253-15 & hr_6_kk & KU567277 \\
\hline Hypotrigona ruspolii & BOFAS194-15 & $2 \_6 \_4 \mathrm{k} 2$ & KU567282 \\
\hline Hypotrigona ruspolii & BOFAS256-15 & hg_5_kk & KU567279 \\
\hline Hypotrigona ruspolii & BOFAS255-15 & hg_4_kk & KU567284 \\
\hline Hypotrigona ruspolii & BOFAS252-15 & hr_5_kk & KU567278 \\
\hline Hypotrigona ruspolii & BOFAS258-15 & $4 \_2 \mathrm{~K} 3$ & KU567294 \\
\hline Hypotrigona ruspolii & BOFAS259-15 & $5 \_2 \mathrm{~K} 3$ & KU567297 \\
\hline Hypotrigona ruspolii & BOFAS261-15 & 7_2K3 & KU567295 \\
\hline Hypotrigona ruspolii & BOFAS266-15 & 14_2K3 & KU567292 \\
\hline Meliponula lendiliana & BOFAS141-15 & $2 \_24 \_4 \mathrm{~K} 2$ & KU146611 \\
\hline Meliponula lendiliana & BOFAS146-15 & 2_22_4K2 & KU146608 \\
\hline
\end{tabular}

